\title{
P02.184. Abstract withdrawn
}

From International Research Congress on Integrative Medicine and Health 2012

Portland, Oregon, USA. 15-18 May 2012

\section{Abstract withdrawn}

Published: 12 June 2012

doi:10.1186/1472-6882-12-S1-P240

Cite this article as: : P02.184. Abstract withdrawn. BMC Complementary and Alternative Medicine 2012 12(Suppl 1):P240.

Submit your next manuscript to BioMed Central and take full advantage of:

- Convenient online submission

- Thorough peer review

- No space constraints or color figure charges

- Immediate publication on acceptance

- Inclusion in PubMed, CAS, Scopus and Google Scholar

- Research which is freely available for redistribution

Submit your manuscript at www.biomedcentral.com/submit

\section{() Biomed Central}

